\title{
Lidija Božac
}

ORCID: https://orcid.org/0000-0001-6783-7436

University of Ljubljana, Slovenia

\section{Unresolved Childhood Abuse and Neglect in Adulthood: the Emotional Aspect in Relational Family Therapy}

\begin{abstract}
Childhood family abuse or neglect is a traumatic relational experience with potentially long lasting impact on one's psycho-organic and interpersonal world. The purpose of our qualitative research was to deepen the understanding of negative trauma impact on adults' emotional world and to find the ways of recovery through Relational Family Therapy. Seven adults with the history of childhood abuse or neglect participated in the research. The results pointed out potential difficulties in identifying, naming and understanding emotions, differentiating past emotions from the present ones, distinguishing one's own emotions from the projected ones, issues with experiencing the diversity of emotions, and difficulties with emotion regulation and management. Positive changes in these areas were observed in Relational Family Therapy. The findings of this research are a contribution to the understanding of specific emotional problems of adults with the history of childhood abuse or neglect as well as to therapeutic interventions that could lead to recovery.
\end{abstract}

\section{Keywords}

Childhood abuse, childhood neglect, emotions, Relational Family Therapy. 


\section{Introduction}

When we speak of early relations, we primarily refer to relationships in which a child should feel protected, where their basic human needs are supposed to be satisfied, and where conditions for their physical, psychological and social growth and development are fulfilled. The model of attachment that a child establishes with their parents often remains a lifelong model, on the basis of which they establish all their further relationships, particularly intimate ones. For this reason, they will always look for relationships that will remind them of the relationships in the primary family and of the primary affect on the basis of which the psychological structure was built, no matter how painful those relations can be. ${ }^{1}$ The most difficult relational experiences in childhood are definitely those of abuse or neglect in the primary family, which often remain unrecognized. ${ }^{2}$ Here we speak of relational trauma when parents do not respond to or even reject the child's needs, or respond inappropriately, and are not able to regulate the child's internal psychological states through interaction. ${ }^{3}$ Such experiences range from extremely serious traumas with grave long-term consequences that can end up even with death, to less intense, but nevertheless harmful experiences. ${ }^{4}$ More often than individual types, combinations of different types of abuse and neglect appear. It cannot be said, for example, that a mentally abused child has not experienced mental neglect, nor can their emotional needs be fulfilled while they are physically abused. ${ }^{5}$ We must be aware that when such experiences accumulate, negative effects do not simply add up: rather, they influence each other, which implies a qualitative difference in consequences. ${ }^{6}$

${ }^{1}$ C. Gostečnik, Psihoanaliza in sakralno izkustvo, Ljubljana 2018, Brat Frančišek, Teološka fakulteta in Frančiškanski družinski inštitut, p. 193.

2 J. Wendland et al., Links between maltreatment during childhood or adolescence and risk-related substance use among young adults, "Lévolution psychiatrique" 82 (2017), p. e24.

C. Gostečnik, Govorica telesa v psihoanalizi, Ljubljana 2012, Brat Frančišek, Teološka fakulteta Univerze v Ljubljani in Frančiškanski družinski inštitut, pp. 126-127.

${ }^{4}$ D. J. Siegel, Pocket guide to interpersonal neurobiology: An integrative handbook of the mind, New York 2012, W. W. Norton \& Company, pp. 39-4.

${ }^{5}$ C. Doyle, C. Timms, Child neglect and emotional abuse: Understanding, assessment and response, Los Angeles 2014, Sage, p. 5.

${ }^{6}$ M. Cloitre et al., A developmental approach to complex PTSD: Childhood and adult cumulative trauma as predictors of symptom complexity, "Journal of Traumatic Stress" 22 (2009) 5, p. 405. 
The latter can be extremely complex, accompanied by various PTSD symptoms, as well as numerous disorders of self-regulatory abilities. ${ }^{7}$ Chronically traumatized children and adults who have experienced abuse or neglect can have severe problems with sensory and emotional regulation, as well as with attachment, and their sense of coherent personal identity and abilities can be severely damaged. ${ }^{8}$ Research on epigenetic neurological changes shows that in these children, specific, permanent stress responses are created that pose an additional risk that even in adulthood they will be more vulnerable to the development of psychological disorders and dysfunctional behaviour through which they will attempt to regulate their internal states (emotions and moods). ${ }^{9}$

\subsection{Emotional aspect}

Each emotion has its roots in visceral and skeletal sensations, and in the sensations of the autonomic nervous system, where the procedural memory associated with traumatic experiences is also stored.$^{10}$ Traumatized people are afraid of reexperiencing these extremely unpleasant emotions and sensations, so instead of reacting to messages their emotions try to convey, they do everything they can in order to not feel them. ${ }^{11}$ They often dissociate, they are not able to experience all emotions, their emotional reactions are seemingly not reality-based, ${ }^{12}$ they are emotionally numb and have difficulties in emotionally connecting with other

M. Scheffers et al., Negative body experience in women with early childhood trauma: Associations with trauma severity and dissociation, "European Journal of Psychotraumatology" 8 (2017) https://www.ncbi.nlm.nih.gov/pmc/articles/PMC5475325/pdf/zept-8-1322892.pdf (10.09.2018).

${ }^{8}$ B. A. Van der Kolk, The body keeps the score: Brain, mind, and body in the healing of trauma, New York 2015, Penguin Books, p. 168.

J. Wendland et al., Links between maltreatment during childhood or adolescence and risk-related substance use among young adults, "Lévolution psychiatrique" 82 (2017), p. e23.

${ }^{10}$ R. Scaer, 8 keys to brain-body balance, New York 2012, W. W. Norton \& Company, pp. 64-65.

${ }^{11}$ B. A. Van der Kolk, Posttraumatic stress disorder and the nature of trauma, in: M. F. Solomon, D. J. Siegel (eds.), Healing trauma: Attachment, mind, body, and brain, New York 2003, Norton, p. 170.

${ }^{12}$ B. Rothschild, The body remembers: The psychophysiology of trauma and trauma treatment, New York 2000, W. W. Norton \& Company, pp. 65-67. 
people. ${ }^{13}$ The ability to experience positive emotions is also severely affected, as they often associate them with danger. They tend to suffer from alexithymia, and because they are not in contact with their own emotions, they lack motivation to be active. On the other hand, they experience their emotions as urges that need to be acted on as soon as possible, without thinking about them. Re-experiencing original traumatic emotions can lead to impulsive, irrational and conflicting behaviours (freezing, feeling helpless, verbal or physical outbursts $)^{14}$ precisely due to insufficient mentalization and integration of emotional experiences. ${ }^{15}$ They cannot even name their emotions and they often perceive them as physical problems. For example, instead of feeling angry or sad, they suffer from pain in the muscles, bowel problems, or some other symptoms with no obvious physical cause. ${ }^{16}$ One of the most long-term effects of early relational trauma are problems with affect regulation. ${ }^{17}$ Affect regulation is one of the basic conditions of proper neural integration and thus the basis of self-regulation. The inability of integration, self-regulation, and emotional regulation are signs of unresolved trauma, where the flow of energy and information becomes either chaotic or rigid. This leads to dysfunctional behaviour in an individual's interpersonal as well intrapersonal world. ${ }^{18}$ Deficiencies in the recognition and processing of emotions are closely linked to deficiencies in language and symbolic representation. Affect regulation is carried out through language, since it enables conscious processing of experiences and their integration. This is especially important, as trauma often occurs on the non-verbal or even pre-verbal level. ${ }^{19}$

${ }^{13}$ B. A. Van der Kolk, The body keeps the score: Brain, mind, and body in the healing of trauma, New York 2015, Penguin Books, p. 14.

${ }^{14}$ P. Ogden, K. Minton, C. Pain, Trauma and the body: A sensorimotor approach to psychotherapy, New York 2006, W. W. Norton \& Company, p. 293.

${ }^{15}$ T. M. Yates, The developmental psychopathology of self-injurious behavior: Compensatory regulation in posttraumatic adaptation, "Clinical Psychology Review" 24 (2004), p. 56.

${ }^{16}$ B. A. Van der Kolk, The body keeps the score: Brain, mind, and body in the healing of trauma, New York 2015, Penguin Books, p. 100.

${ }^{17}$ R. Cvetek et al., Spirituality and psycho-organic regulation, "The Person and the Challenges" 8 (2018) 2, p. 160.

${ }^{18}$ D. J. Siegel, An interpersonal neurobiology of psychotherapy: The developing mind and the resolution of trauma, in: M. F. Solomon, D. J. Siegel (eds.), Healing trauma: Attachment, mind, body, and brain, New York 2003, Norton, p. 43.

${ }^{19}$ T. M. Yates, The developmental psychopathology of self-injurious behavior: Compensatory regulation in posttraumatic adaptation, "Clinical Psychology Review" 24 (2004), p. 55. 


\subsection{Frequent adulthood emotions which are related to abuse or neglect}

Adults who experienced abuse or neglect often feel intense shame; ${ }^{20}$ shame can even become the focal point around which one's relatively stable identity and one's life narrative is being organized. ${ }^{21}$ There are frequent feelings of being stigmatized, feelings of guilt and sense of responsibility for what happened to them $;{ }^{22}$ feelings of powerlessness ${ }^{23}$ and disgust. ${ }^{24}$ Sexual abuse in particular leaves in its wake enormous amounts of disgust $;^{25}$ these individuals are overwhelmed by intense fear and feelings of being threatened, which they try to control by behaviours that are just as extreme (e.g. self-harming behaviour), ${ }^{26}$ or by excessive monitoring the surroundings in order to discover potential danger. ${ }^{27}$ They may relive horror ${ }^{28}$ and are eventually no longer capable of distinguishing dangerous from unthreatening situations; consequently, they find themselves in the role of victim again and again. ${ }^{29}$ They often direct their anger towards themselves (in the form of depression, self-hatred, and/ or self-destructive behaviour) or to their loved ones. It is difficult for them

${ }^{20}$ L. Smolak, Sexual abuse and body image, in: T. F. Cash, L. Smolak (eds.), Body image: A handbook of science, practice, and prevention, 2nd ed., New York 2012, The Guilford Press, p. 121.

${ }^{21}$ J. Pinto-Gouveia, M. Matos, Can shame memories become a key to identity? The centrality of shame memories predicts psychopathology, "Applied Cognitive Psychology" 25 (2011), p. 287.

${ }^{22}$ T. M. Karr, H. Simonich, Psychological trauma and body image, in: T. F. Cash (ed.), Encyclopedia of body image and human appearance, New York 2012, Norton, p. 703.

${ }^{23}$ R. Scaer, 8 keys to brain-body balance, New York 2012, W. W. Norton \& Company, p. 107.

${ }^{24}$ E. Borgmann et al., Standardized mirror confrontation: Body-relatedemotions, cognitions and level of dissociation in patients with posttraumatic stress disorder after childhood sexual abuse, "Borderline Personality Disorder and Emotion Dysregulation", 1 (2014) 10 http://www.bpded. com/content/1/1/10 (10.08.2017).

${ }^{25}$ T. Repič Slavič, Nemi kriki spolne zlorabe in novo upanje. 2nd ed., Celje 2015, Celjska Mohorjeva družba, Društvo Mohorjeva družba, p. 31.

${ }^{26}$ L. Smolak, Sexual abuse and body image, in: T. F. Cash, L. Smolak (eds.), Body image: A handbook of science, practice, and prevention, 2nd ed., New York 2012, The Guilford Press, p. 121.

${ }^{27}$ E. Romano, R. V. De Luca, Evaluation of a treatment program for sexually abused adult males, "Journal of Family Violence" 21 (2006) 1, p. 76.

${ }^{28}$ P. Ogden, K. Minton, C. Pain, Trauma and the body: A sensorimotor approach to psychotherapy, New York 2006, W. W. Norton \& Company, p. 12.

${ }^{29}$ B. Rothschild, The body remembers: The psychophysiology of trauma and trauma treatment, New York 2000, W. W. Norton \& Company, p. 61. 
to express anger in a constructive way, which can lead to chronic irritability and outbreaks of anger. They try to suppress it, however, since they feel that they have no right to be angry..$^{30}$ Anger often conceals other emotions, the recognition of which would mean even higher vulnerability (e.g. sadness, the feeling of loss).$^{31}$ Sadness is another frequently experienced affect, closely connected to the feeling of loss. ${ }^{32}$ Relational Family Therapy pays special attention to the affective aspect of unresolved trauma.

\subsection{Treatment of early relational trauma in Relational Family Therapy}

The Relational Family Therapy model is based on the intrapsychic, intrapersonal and systemic experience of an individual, subsystems (marital, children's), the system (family) as well as the environment they live in. The fundamental assumption of the RFT model is based on the recognition that the experiences of childhood, physical sensations and, in particular, the basic affects which accompany them, repeat throughout one's life as relationship patterns on organic, psychological and social levels. They are founded on the human need to maintain the sense of belonging to the personal world of affective relations that established the individual's psychological structure and connected them with others in their childhood. ${ }^{33}$ Counter transference will enable the therapist to understand the individual's experience, thus opening the space of activity within therapeutic relationship, ${ }^{34}$ because the therapist will first become the recipient of the client's unacceptable affect herself, and then she will try to internally regulate these affects and return them to the client in a more acceptable form. In doing so, a wide variety of body sensations,

${ }^{30}$ K. Kendall-Tackett, Chronic pain: The next frontier in child maltreatment research, "Child abuse and neglect" 25 (2001) https://pdfs.semanticscholar.org/3del/ c287bb1b9ed75bb4d651d26b3812822c19f9.pdf (12.07.2017).

${ }^{31}$ E. Romano, R. V. De Luca, Evaluation of a treatment program for sexually abused adult males, "Journal of Family Violence" 21 (2006) 1, p. 87.

${ }^{32}$ R. Scaer, 8 keys to brain-body balance, New York 2012, W. W. Norton \& Company, p. 97.

${ }^{33}$ C. Gostečnik, Relacijska družinska terapija, in: B. Simonič (ed.), Relacijska družinska terapija v teoriji in praksi, Ljubljana 2015, Teološka fakulteta in Frančiškanski družinski inštitut, pp. 7-9.

${ }^{34}$ R. Cvetek, Travmatična izkušnja in relacijska družinska terapija, in: B. Simonič (ed.), Relacijska družinska terapija v teoriji in praksi, Ljubljana 2015, Teološka fakulteta in Frančiškanski družinski inštitut, p. 52. 
which she will experience during therapy, will be especially helpful, because it is an unconscious right-hemispheric communication between her and the client, through which the latter will also establish a new way of regulating unacceptable contents. ${ }^{35}$ Changes in therapy take place at the cognitive level (cognitive recognition of difficult experiences, connection of these with the present, awareness of dissociated parts), the emotional level (addressing emotions, affects and body sensations) and the body level (letting go of various defence mechanisms, reliving body sensations and responses from the original experience)..$^{36}$ In our study, we focused on revealing and resolving early relational trauma at the emotional level.

\section{Method}

The purpose of the research was to discover how the unresolved abuse or neglect trauma manifests at the emotional level in adulthood and whether Relational Family Therapy can bring about changes at this level. We formed a therapeutic group of seven participants (five women and two men) aged 22 to 62 years who had experienced abuse or neglect during childhood, which we tested with the CECA.Q questionnaire (Childhood Experience of Care and Abuse Interview). Group work was conducted according to the Relational Family Therapy method. For data analysis, the grounded theory method and the content analysis method was used. The main source of information were the transcripts of conversations that were conducted during therapeutic meetings, answers to the CECA.Q questionnaire and written hand-outs of the participants. The textual corpus was then broken down into individual semantic units that were sorted into categories and subcategories by open coding procedures. Then, by means of axial coding, we connected lower-order categories to higher-order ones.

\footnotetext{
${ }^{35}$ C. Gostečnik, Inovativna relacijska družinska terapija: inovativni psihobiološki model, Ljubljana 2011, Brat Frančišek, Teološka fakulteta Univerze v Ljubljani in Frančiškanski družinski inštitut, p. 36.

${ }^{36}$ T. Repič Slavič, Spolna zloraba in relacijska družinska terapija, in: B. Simonič (ed.), Relacijska družinska terapija v teoriji in praksi, Ljubljana 2015, Teološka fakulteta in Frančiškanski družinski inštitut, pp. 75-81.
} 


\section{Results}

The experience of abuse or neglect primarily means the abuse of security and trust by those whom clients as children trusted most, so the first task in therapy was to establish security and trust between the client and the therapist. This was enabled by an empathetic and respectful relationship with clearly defined boundaries. ${ }^{37}$ Only when the sense of security was established, working with emotions became possible. During therapy, problems were recognized in the following areas: understanding emotions, finding words to express emotions, distinguishing past feelings from the present ones, gaining permission to experience all feelings, affect regulation and affect management. In these areas, we also observed potential changes.

In the course of therapy, it was first necessary to establish an understanding of what emotions are and what they are intended for, as the participants feared difficult affects and perceived them as unmanageable. At first, they were not aware of their function and how to deal with them, but gradually they began to be aware of their importance and that they provide them with information about themselves and their needs.

"It was interesting when we talked about anger, but essentially the same goes for all emotions: if we keep them within, they become harmful. And I feel that all emotions are good, even though there are some I don't want to feel - horror, for example - but now I know that horror has its function, too."

The participants had many problems in naming the feelings they experienced. They found it hard to find the right words for certain emotions, particularly heavy and traumatic ones, since in childhood there was usually no one to help them express what they felt. Finding the appropriate words for one's own emotions was the first step towards their regulation. At the beginning of therapy, negative emotions were most often expressed as some sort of general dissatisfaction. Only gradually the participants became able to more precisely define what they felt.

»A lack of self-esteem, insufficient preservation of my own integrity, misplaced feelings of guilt, a mistaken sense of responsibility for certain things, shame, inadequacy, non-acceptance of myself and others, false self-image.»

${ }^{37}$ T. Repič Slavič, C. Gostečnik, Relational family therapy as an aid toward resolving the trauma of sexual abuse in childhood in the process of separation in the couple relationship, "Journal of marital and family therapy" 43 (2017) 3, p. 425. 
Likewise, it was difficult for them to distinguish between emotions that stemmed from past trauma and those that originated from the present, since unresolved traumatic emotions often emerged in current situations, without participants being aware of that.

»When my children start behaving wilfully, I simply can't stand it. It annoys me so much that I can barely restrain myself from hitting them; I would do anything for them to stop."

In the primary family, they were often not allowed to feel certain emotions if they wanted to maintain the connection with their parents. Most frequently, it was forbidden to experience anger, rage, and sadness.

"I remember how sometimes I cried because I was sad, and how my father said that if I didn't stop, he would give me a good hitting, so that I'd at least know why I was crying."

The therapeutic group gradually developed a safe space where clients could feel and express all feelings, regardless of the fact that in the past they were forbidden to do so. The mechanism of transference and counter transference played an important role in this process, as it often happened that with their behaviour, they aroused emotions in the therapist as well as in each other that they did not want to feel themselves. The very feeling of healthy anger makes it possible to establish appropriate boundaries and self-esteem, and enables the resistance against abuse or neglect. ${ }^{38}$

Only later, one of the participants could feel her anger towards her mother.

"Yes, I'm mad at her... The things she did to me... No mother can do such things to her child..."

The main focus of the therapy was that the participants, with the help of the therapist, experienced proper regulation of their emotions, especially the most difficult ones. Due to their experience in the family where abuse or neglect prevailed, their affect regulation was inadequate or dysfunctional. In therapy, the inability to tolerate and regulate heavy emotions was reflected in many intrapersonal and interpersonal conflicts that they themselves were not able to resolve. »...When I get really mad I don't know what I'm doing anymore. I'm simply not myself.«

${ }^{38}$ T. Repič Slavič, C. Gostečnik, Relational family therapy as an aid toward resolving the trauma of sexual abuse in childhood in the process of separation in the couple relationship, "Journal of marital and family therapy" 43 (2017) 3, p. 432. 
Heavy emotions were transferred to the therapist through projection-introjection identification, which enabled her to feel the client's experiences and emotions fully. Her acknowledging these emotions, processing them and returning them to a client in a more acceptable form was the basic mechanism through which participants gradually learned self-regulation.

"The other day, when I came home from a therapy session, I cried when I was thinking about the things I was talking about. I was very sad, but I finally calmed down and I could go to sleep. In the past I was not able to sleep, I suffered all night, or I would take a sleeping pill.«

Since in the family of origin there was no one who would teach the child the meaning of appropriate and inappropriate expression of emotions, or adults expected the child to regulate their emotions, therapy also became a place where participants tried to learn how to manage the feelings of others. At the beginning of therapeutic meetings, the clients' identification with their perpetrators' emotions was observed. Most often, these were feelings of guilt, responsibility, as well as shame and anger.

»I still feel such guilt and responsibility towards my parents; that I'm responsible for their being so unhappy, and that I have to correct this. That this is my duty! «

With the help of the therapist who consistently kept addressing what was going on, they gradually learned to distinguish the emotional projections of the perpetrators and to establish a distance between them, which brought them great relief. This was closely connected with the issue of self-awareness and the separation of the victim from the perpetrator.

"Actually, this isn't my problem, and I don't know why I have to deal with what my mom suffered from her parents, her mother-in-law and her husband, and I don't know who else... I'm fed up with that, it's her who should deal with that, I'm not her mother. I have enough things to worry about. I have to take care of myself and my daughter, and mother has to take care of herself.»

\section{Discussion}

Abuse and neglect can negatively impact many areas in a child's life, which can continue into adulthood in the absence of factors that allow rehabilitation. $\mathrm{Nu}$ merous scientific studies confirm the complexity of negative adjustments that can be reflected in victims' physical, psychological and social health. In fact, this 
is a functional adaptation of a child to the experience of interpersonal trauma, but used in adulthood, this adaptation becomes dysfunctional. ${ }^{39}$ When working with traumatized individuals, the goal of Relational Family Therapy is therefore to face the client with their basic affects and the way how they regulate their psycho-organic states, and above all, to achieve change in their regulating these states in the present, ${ }^{40}$ which gradually resolves the old and creates new patterns of confrontation with oneself, others, and life's challenges. In therapy, the primary concern was the establishment of a safe, trustworthy space between the client and the therapist, since one of the worst children's experiences was that the perpetrator was someone with whom they were emotionally connected and whom they trusted.$^{41}$ From this fundamental abuse of trust, problems arise that relate to building trust in others in adult relationships as well as self-trust. ${ }^{42}$ This also involves problems in affect regulation, particularly the ability to regulate the most severe affects. An individual who, as a child, could not learn to regulate their psychobiological states, because their parents did not enable this or they, with their actions, even intensified the child's already insufferable affects, can maintain the inability to tolerate and regulate difficult affects in adulthood. ${ }^{43}$ Early trauma supports inadequate emotional regulation and the regulation of the autonomic nervous system. We can say that such brain constantly looks for a way to achieve regulation, calm and stability (amygdala). ${ }^{44}$ Our research also showed that clients had problems in affect regulation, which needed the therapist's help. When clients continued to experience the regulation of their emotions with her, they slowly established their own mechanisms that, firstly, enabled them to feel emotions without being afraid of them, and then gradually

${ }^{39}$ B. A.Van der Kolk et al., Disorders of extreme stress: The empirical foundation of a complex adaptation to trauma, "Journal of Traumatic Stress" 18 (2005) 5, p. 396.

${ }^{40}$ C. Gostečnik, Govorica telesa v psihoanalizi, Ljubljana 2012, Brat Frančišek, Teološka fakulteta Univerze v Ljubljani in Frančiškanski družinski inštitut, p. 281.

${ }^{41}$ K. Kendall-Tackett, Chronic pain: The next frontier in child maltreatment research, "Child abuse and neglect" 25 (2001) https://pdfs.semanticscholar.org/3del/ c287bb1b9ed75bb4d651d26b3812822c19f9.pdf (12.07.2017).

${ }^{42}$ R. Barnes, N. Josefowitz, Forensic assessment of adults reporting childhood sexualized assault: Risk, resilience, and impacts, "Psychological injury and law" 7 (2014) 1 http://link. springer.com.nukweb.nuk.uni-lj.si/article/10.1007\%2Fs12207-014-9184-0 (27.07.2016).

A. N. Schore, Early relational trauma, disorganized attachment, and the development of a predisposition to violence, in: M. F. Solomon, D. J. Siegel (eds.), Healing trauma: Attachment, mind, body, and brain, New York 2003, Norton, p. 108.

${ }^{44}$ R. Scaer, 8 keys to brain-body balance, New York 2012, W. W. Norton \& Company, p. 71. 
developed their own ability to regulate emotions, beginning with those less intense. One of the essential elements of change is the very affect regulation, when the client in the relation with the therapist constantly experiences arousal calming down and at the same time learns self-regulation. ${ }^{45}$ Therapy showed that the shortcomings in emotional processing were closely linked with the ability to name emotions, deficiencies in language and symbolic representation, which often posed a problem for clients. It is through the language that the regulation of affects is carried out, since it enables them to consciously process and integrate their experiences. This is especially important, as trauma often occurs at a non-verbal or even pre-verbal level. ${ }^{46}$

This also became apparent during therapeutic meetings where participants in the beginning found it difficult to find the right words for their feelings and affects, particularly difficult and traumatic ones, since in childhood there was usually no one to help them express what they felt. When they were able to name them appropriately, this meant that they got connected with them. Since in the primary family they did not learn what the proper expression of emotions meant, therapy became a place where they tried to manage emotions in a different way than they had been used to. They were finally allowed to experience all feelings, particularly those that they were forbidden even to feel, let alone express in their primary family. The mechanisms of transference and counter-transference played an important role in this process: with their behaviour participants often awakened emotions in the therapist, as well as in each other, that they did not want to feel themselves. In most cases, these were anger, rage, contempt, disgust, shame and sadness - as it turned out in therapy, they originated from traumatic childhood experiences. One of the important tasks, therefore, was to learn how to distinguish between emotions that are rooted in the past from those that are part of the present. One often perceives and responds to present events and persons in a similar way as one perceived and responded to similar events and persons in the past. ${ }^{47}$ It is essential for a traumatized client to distinguish the present from the past not only at the cognitive level, but also - even more - emotionally and at the level of sensations, as this is the only way for them to begin

${ }^{45}$ C. Gostečnik, Relacijska paradigma in travma, Ljubljana 2008, Brat Frančišek in Frančiškanski družinski inštitut, p. 292.

${ }^{46}$ T. M. Yates, The developmental psychopathology of self-injurious behavior: Compensatory regulation in posttraumatic adaptation, "Clinical Psychology Review" 24 (2004), p. 55.

${ }^{47}$ R. Cvetek et al., Spirituality and psycho-organic regulation, "The Person and the Challenges" 8 (2018) 2, p. 161. 
to live again in the present. ${ }^{48}$ This double awareness enables an individual to be conscious of what he is experiencing now is only reliving the original trauma, which allows him to distance himself from it and brings the feeling that it is manageable, thus creating a new experience. ${ }^{49}$ The participants began to realize that feelings and affects are valuable because they provide them with information about themselves, help with right choices and self-care and do not have to be feared or avoided. Traumatized people lose the ability to motivate their behaviour by emotions, they may suffer from alexithymia and a lack of motivation to be active, or, on the other hand, perceive their emotions as urges that need to be acted on as soon as possible without thinking about them, and possibly deciding on more appropriate behaviour..$^{50}$ As one of unresolved contents, therapy has also shown the need for individuals to learn to distinguish their own emotions from others' projected emotions. Closely related to that one was the issue of self-awareness and distinguishing the victim from the perpetrator, as their boundaries were often brutally violated in childhood. Reconnection with their own feelings therefore meant reconnecting with themselves - an awareness who they are and what they need. As the aim of the therapy dealing with unresolved trauma is to strengthen the ability of self-regulation and emotional processing, the success of therapy can be measured in the individual's greater capability to choose when responding to events in the external and internal world, and to achieve better external and internal integration..$^{51}$

\section{Limitations}

The research was carried out on a small sample, therefore its results cannot be generalized. In addition, the participants themselves reported changes, which

${ }^{48}$ C. Gostečnik, Relacijska paradigma in travma, Ljubljana 2008, Brat Frančišek in Frančiškanski družinski inštitut, p. 294.

${ }^{49}$ T. Repič Slavič, C. Gostečnik, Relational family therapy as an aid toward resolving the trauma of sexual abuse in childhood in the process of separation in the couple relationship, "Journal of marital and family therapy" 43 (2017) 3, p. 427.

${ }^{50}$ P. Ogden, K. Minton, C. Pain, Trauma and the body: A sensorimotor approach to psychotherapy, New York 2006, W. W. Norton \& Company, p. 11.

${ }^{51}$ D. J. Siegel, An interpersonal neurobiology of psychotherapy: The developing mind and the resolution of trauma, in: M. F. Solomon, D. J. Siegel (eds.), Healing trauma: Attachment, mind, body, and brain, New York 2003, Norton, pp. 43-44. 
is why there is a strongly subjective aspect. Similarly, the survey did not include follow-up with checking whether changes were of a lasting nature so that the participants would also report change after a longer period of time. Another limitation is that the participants reported change to the same therapist who conducted therapy meetings and it is possible that to some extent they wanted to please her with their answers. Lastly, other factors that could support or hinder the achievement of change were not controlled.

\section{Conclusion}

The results of the research deepen the understanding of the emotional aspect of unresolved abuse or neglect, and how emotional adjustments to early relational trauma and the associated developmental deficiencies are maintained into adulthood. Emotional adjustments that were functional during a traumatic experience (dissociation, freezing, emotional numbness, reactive behaviour, dysfunctional affect regulation), can become an obstacle both at intrapsychic and interpersonal levels in adulthood. In childhood experiences, Relational Family Therapy reveals the foundation of these adjustments, as well as potential pathways that enable their fundamental transformation. It is important for change to occur precisely in those segments that have remained deeply dysfunctional after the trauma, which are mainly affect regulation and the integration of past experiences. However, further research will be needed to understand and find potential solutions to the emotional scars left by trauma.

\section{Bibliography}

Barnes R., Josefowitz N., Forensic assessment of adults reporting childhood sexualized assault: Risk, resilience, and impacts, "Psychological injury and law" 7 (2014) Nr. 1 http://link.springer.com.nukweb.nuk.uni-lj.si/article/10.1007\%2Fs12207-014-9184-0 (27.7.2016).

Borgmann E., Kleindienst N., Vocks S., Dyer A. S., Standardized mirror confrontation: Body-related emotions, cognitions and level of dissociation in patients with posttraumatic stress disorder after childhood sexual abuse, "Borderline Personality Disorder and Emotion Dysregulation" 1 (2014) Nr. 10 http://www.bpded.com/content/1/1/10 (10.08.2017).

Cloitre M., Stolbach B. C., Herman J. L., Van der Kolk B. A., Pynoos R., Wang J., Petkova E., A developmental approach to complex PTSD: Childhood and adult cumulative 
trauma as predictors of symptom complexity, "Journal of Traumatic Stress" 22 (2009) Nr. 5, pp. 399-408.

Cvetek R., Travmatična izkušnja in relacijska družinska terapija, in: B. Simonič (ed.), Relacijska družinska terapija $v$ teoriji in praksi, Ljubljana 2015: Teološka fakulteta in Frančiškanski družinski inštitut, pp. 49-66.

Cvetek R., Gostečnik C., Pate T., Simonič B., Valenta T., Repič Slavič T., Spirituality and psycho-organic regulation, "The Person and the Challenges" 8 (2018) Nr. 2, pp. 147-166.

Doyle C., Timms C., Child neglect and emotional abuse: Understanding, assessment and response, Los Angeles 2014: Sage.

Gostečnik C., 2018. Psihoanaliza in sakralno izkustvo, Ljubljana 2018: Brat Frančišek, Teološka fakulteta in Frančiškanski družinski inštitut.

Gostečnik C., Relacijska družinska terapija, in: B. Simonič (ed.), Relacijska družinska terapija $v$ teoriji in praksi, Ljubljana 2015: Teološka fakulteta in Frančiškanski družinski inštitut, pp. 9-33.

Gostečnik C., Govorica telesa v psihoanalizi, Ljubljana 2012: Brat Frančišek, Teološka fakulteta Univerze v Ljubljani in Frančiškanski družinski inštitut.

Gostečnik C., Inovativna relacijska družinska terapija: inovativni psihobiološki model, Ljubljana 2011: Brat Frančišek, Teološka fakulteta Univerze v Ljubljani in Frančiškanski družinski inštitut.

Gostečnik C., Relacijska paradigma in travma, Ljubljana 2008: Brat Frančišek in Frančiškanski družinski inštitut.

Karr T. M., Simonich H., Psychological trauma and body image, in: T. F. Cash (ed.), Encyclopedia of body image and human appearance, New York 2012: Norton, pp. 700-706.

Kendall-Tackett K., Chronic pain: The next frontier in child maltreatment research, "Child abuse and neglect" 25 (2001)

https://pdfs.semanticscholar.org/3del/c287bb1b9ed75bb4d651d26b3812822c19f9.pdf (12.07.2017).

Ogden P., Minton K., Pain C., Trauma and the body: A sensorimotor approach to psychotherapy, New York 2006: W. W. Norton \& Company.

Pinto-Gouveia J., Matos M., Can shame memories become a key to identitiy? The centrality of shame memories predicts psychopathology, "Applied Cognitive Psychology" 25 (2011) pp. 281-290.

Repič Slavič, T. Nemi kriki spolne zlorabe in novo upanje. 2nd ed. Celje 2015: Celjska Mohorjeva družba in Društvo Mohorjeva družba.

Repič Slavič, T., Spolna zloraba in relacijska družinska terapija, in: B. Simonič (ed.), Relacijska družinska terapija $v$ teoriji in praksi, Ljubljana 2015: Teološka fakulteta in Frančiškanski družinski inštitut, pp. 67-83.

Repič Slavič, T., Gostečnik C., Relational family therapy as an aid toward resolving the trauma of sexual abuse in childhood in the process of separation in the couple relationship, "Journal of marital and family therapy" 43 (2017) 3, pp. 422-434. 
Romano E., De Luca R. V., Evaluation of a treatment program for sexually abused adult males, "Journal of Family Violence" 21 (2006) 1, pp. 75-88.

Rothschild B., The body remembers: The psychophysiology of trauma and trauma treatment, New York 2000: W. W. Norton \& Company.

Scaer R., 8 keys to brain-body balance, New York 2012: W. W. Norton \& Company.

Scheffers M., Hoek M., Bosscher R. J., van Dujn M. A. J., Schoevers R. A., van Busschbach J. T., Negative body experience in women with early childhood trauma: Associations with trauma severity and dissociation, "European Journal of Psychotraumatology" 8 (2017) https://www.ncbi.nlm.nih.gov/pmc/articles/PMC5475325/pdf/zept-81322892.pdf (10.09.2018).

Schore A. N., Early relational trauma, disorganized attachment, and the development of a predisposition to violence, in: M. F. Solomon, D. J. Siegel (eds.), Healing trauma: Attachment, mind, body, and brain, New York 2003: Norton, pp.107-167.

Siegel D. J., Pocket guide to interpersonal neurobiology: An integrative handbook of the mind, New York 2012: W. W. Norton \& Company.

Siegel D. J., An interpersonal neurobiology of psychotherapy: The developing mind and the resolution of trauma, in: M. F. Solomon, D. J. Siegel (eds.), Healing trauma: Attachment, mind, body, and brain, New York 2003: Norton, pp. 1-56.

Smolak L., Sexual abuse and body image, in: T. F. Cash, L. Smolak (eds.), Body image: A handbook of science, practice, and prevention, 2nd ed., New York 2012: The Guilford Press, pp. 119-126.

Van der Kolk B. A., The body keeps the score: Brain, mind, and body in the healing of trauma, New York 2015: Penguin Books.

Van der Kolk B. A., Posttraumatic stress disorder and the nature of trauma, in: M. F. Solomon, D. J. Siegel (eds.), Healing trauma: Attachment, mind, body, and brain, New York 2003: Norton, pp. 168-195.

Van der Kolk B. A., Roth S., Pelcovitz D., Sunday S., Spinazzola J., Disorders of extreme stress: The empirical foundation of a complex adaptation to trauma, "Journal of Traumatic Stress" 18 (2005) 5, pp. 389-399.

Wendland J., Lebert A., de Oliveira C., Boujut E., Links between maltreatment during childhood or adolescence and risk-related substance use among young adults, "L'évolution psychiatrique" 82 (2017), pp. e17-e26.

Yates T. M., The developmental psychopathology of self-injurious behavior: Compensatory regulation in posttraumatic adaptation, "Clinical Psychology Review” 24 (2004), pp. 35-74. 